\title{
Examining Prospective Teachers' Mathematical Communication Skills in Statistics
}

\author{
$1^{\text {st }}$ Djamilah Bondan Widjajanti \\ Mathematics \& Natural Science \\ Faculty \\ Yogyakarta State University \\ Yogyakarta, Indonesia \\ djamilah_bw@uny.ac.id \\ $4^{\text {th }}$ W. Setyaningrum \\ Mathematics \& Natural Science \\ Faculty \\ Yogyakarta State University \\ Yogyakarta, Indonesia
}

\author{
$2^{\text {nd }}$ E. Listyani \\ Mathematics \& Natural Science \\ Faculty \\ Yogyakarta State University \\ Yogyakarta, Indonesia
}

\author{
$3^{\text {rd }}$ M. Susanti \\ Mathematics \& Natural Science \\ Faculty \\ Yogyakarta State University \\ Yogyakarta, Indonesia
}

\begin{abstract}
The mathematical communication skill is an important thing to support the teachers' role as facilitators in helping students to master 21st-century skills. The efforts to improve the skill must be well prepared since they are still as prospective teachers. The communication skill involves some aspects. Therefore, to improve the skill of prospective teachers, it must be identified what aspects need to be improved. This study aims to describe students' mathematical communication skills in Statistics. The mathematical communication skills in this study refer to the students' skills to 1) present the data or information into table or diagram correctly, 2) use mathematical terms, symbols/notations, charts, diagram, illustrations or formulas correctly, 3) solve the problems correctly and systematically, and 4) provide the correct reasons or explanations on the solution they got. The participants of this study are 35 students of Mathematics Education Department, Yogyakarta State University who enroll in Statistics course during September - December 2016. The data of this study are collected from the midterm exam and final exam of the semester. The research shows: 1) the students' mathematical communication skills in Statistics are at the medium level; 2) the ability to use correct mathematical terms, symbols/notations, charts, diagram, illustrations or formulas seems to be the lowest one among the four skills measured in this study; and 3) most students have difficulties in solving problems related to probability. The results indicate that the students' mathematical communication skills are serious issues that need to be addressed.
\end{abstract}

Keywords—prospective math teachers, communication skills, statistics

\section{INTRODUCTION}

To survive and succeed in the 21 st century, a person is required to master the skills such as: 1) life and career skills, 2) learning and innovation skills, 3 ) information, media, and technology skills [1]. A good quality education can master these skills. Therefore, every teacher in the school is obliged to realize good quality education, at least in their respective class, likewise with the math teacher.

To realize a good quality education, one of the skills that must be mastered by mathematics teachers is the skill of scientific communication because having this skill makes math lesson easier for students. Mathematics teachers who do not have adequate mathematical communication skills, for example, cannot give an explanation when there are students who ask the origin of a formula, or inconsistent in using symbols, or less precise in making illustrations/sketches, can make students more difficult learn math. It is indeed not desirable. The difficulties in learning mathematics can reduce the motivation of students to learn, whereas some research results indicate that there is a positive correlation between motivation and learning achievement [2-4]. To improve students' learning motivation, this mathematical communication skill of math teacher needs to get attention.

Some experts mentioned about the importance of mathematical communication skills. Mathematical communication skills play a crucial role in mathematics class. It is an essential part of mathematics and mathematics education [5-6]. Mathematical communication skills is an essential process for learning mathematics because through communication, students reflect upon, clarify and expand their ideas and understanding of mathematical relationships and mathematical argument [7].

The importance of mathematical communication skills in mathematics education is reflected by the fact that this aspect is included in mathematics activities in the mathematics curricula in many countries. In Indonesia, one of the objectives of why mathematics is given in school is so that the students are able to communicate some ideas with symbols, table, diagram or other media to clarify the situation or problem. For students, involving in mathematic communication, either with a teacher or his friends, either orally or written, either at the same time with the learning process or outside the class, will give many advantages to improve their mathematical understanding [5]. Besides, the use of mathematical language helps students gain insights into their thinking and develop and express their mathematical ideas and strategies, precisely and coherently, to themselves and the others [8].

Noting the importance of mathematics teachers having adequate mathematical communication skills, it is also important to pay attention to the education for prospective math teachers. Efforts to improve mathematical communication skills of prospective math teachers should 
be done continuously and integrated through lectures. One of them can be through the lectures of Statistics.

Statistics is a general course that must be taken by students at university level, including students of Mathematics Education Program, Faculty of Mathematics and Natural Sciences, Yogyakarta State University, Indonesia. Statistics courses are becoming increasingly important because the need for statistical-literacy in the future will also increase [9]. In the current era of information technology, statistics will help someone to filtering the information by analysis of data, not just opinions.

Statistics, which contains the following topics: 1) Descriptive statistics; 2) Probability; 3) Random variables; 4) Sampling distribution; 5) Confidence interval; and 6) Hypothesis testing, are suitable to develop students' mathematical communication skill because the discussion of the topics use symbols, drawings, tables, diagrams, and explanations. However, as the first step, lecturers need to know how to develop students' mathematical communication skill in Statistics, it must first be identified how is the level of mathematical communication skill possessed by the students, and what aspect is weakest and needs to be improved. For this purpose, this study was conducted.

\section{METHODS}

The type of this research is descriptive. The subjects of this research were 35 first-semester students of Mathematics Education Study Program, Yogyakarta State University, Indonesia, who took Statistics course during September December 2016.

The purpose of the research is to identify which aspects of the communication skills of the prospective mathematics teachers that need to be improved. The mathematical communication skills in this study refer to the students' skills to 1) present the data or information into table or diagram correctly, 2) use mathematical terms, symbols/notations charts, diagram, illustrations or formulas correctly, 3) solve the problems correctly and systematically, and 4) provide the correct reasons or explanations on the solution they got.

The instrument has been developed in the form of two sets of students' mathematical communication skill test in Statistics. Three lecturers of Statistics have validated the instrument. Problems/questions in the form of essays, given at the middle (ME) and the final exam of the semester (FE), each of 5 numbers, each was done within 100 minutes. The instrument for $\mathrm{ME}$ and $\mathrm{FE}$ are both reliable, with the coefficient of Alfa-Cronbach reliability 0.71 and 0.72 , respectively.

Table 1. The Specification of Mathematical Communication Skills at ME and FE

\begin{tabular}{|c|c|c|c|c|c|}
\hline \multirow{2}{*}{ No } & \multirow{2}{*}{ Indicators } & \multicolumn{2}{|c|}{ Question Number } & \multicolumn{2}{|c|}{ Maximum Score } \\
\hline & & ME & FE & ME & FE \\
\hline 1. & Present the data or information in table or diagram correctly & 2,5 & $2,4,5$ & 280 & 420 \\
\hline 2. & $\begin{array}{l}\text { Use mathematical terms, symbols/notations, charts, diagram, } \\
\text { illustrations or formulas correctly }\end{array}$ & $1,3,4,5$ & $1,2,3,4,5$ & 560 & 700 \\
\hline 3. & Solve the problems correctly and systematically & $1,3,4,5$ & $1,2,3,4,5$ & 560 & 700 \\
\hline 4. & $\begin{array}{l}\text { Provide the correct reasons or the explanations of the solution } \\
\text { they got }\end{array}$ & 1,3 & 4,5 & 280 & 280 \\
\hline
\end{tabular}

Table 2. Capabilities Categorization

\begin{tabular}{cc}
\hline Percentage of achievements (\%) & Category \\
\hline $0-29$ & Very Low \\
$30-49$ & Low \\
$50-64$ & Medium \\
$65-79$ & High \\
$80-100$ & Very High \\
\hline
\end{tabular}

The specification for ME and FE is presented in Table 1. The calculation of the maximum score for each indicator has been calculated from the number of questions for the indicator multiplied by the maximum possible score $(=4)$, then multiplied by the number of students $(=35)$. Categories of mathematical communication skills were determined using criteria in Table 2. Percentage of achievement has been calculated from total score achievement obtained divided by the total maximum possible score. From the data that has been collected, the following can be described are: 1) the category of the communication skills of students who were the subjects of this research, 2) the aspects in which students tend to be weak, 3) examples of mistakes made by students.

\section{RESULTS AND DISCUSSION}

Based on ME and FE data from 35 students, students' mathematical communication skill in Statistics can be

described as follows as in Table 3. From Table 3 it can be seen that the standard deviation is relatively small and the data distribution tends to be normal. Besides, Table 2 categorize students 'mathematical communication skills in Statistics. It conveyed that the students' mathematical communication skills in Statistics are in the medium level. Although there has been an increase in achievements in the final exam, it is still in the medium category. this This result need to be followed up by the lecturers of Statistics. The lecturers must improve their learning to improve the communication skills of students in Statistics.

To be able to choose the right way of improving students' mathematical communication skills in Statistics, keep in mind the results of each indicator and what factors are reasonably suspected as the cause. More details, results for each indicator are presented in Table 4.

Table 4 showed that the achievement of students' mathematical communication skill on each indicator is only included at the medium level, and the ability to use correct 
mathematical terms, symbols/notations, charts, diagram, illustrations or formulas seems to be the lowest one among the four skills measured in this study. In fact, for this second indicator, the achievement in ME is only at the "low" level. The results of this study are similar to the results of Widjajanti's research on Discrete Mathematics courses which conclude that students tend to be low on the use of charts, pictures, and illustrations [10]. Regarding that results, it becomes important for the education program of prospective mathematics teacher to explicitly include communication standards in their learning process, as contained in the NCATE/NCTM Program Standards [11].

Table 3. Descriptive Statistics for Mathematical Communication Skills Score

\begin{tabular}{cccc}
\hline Statistics & ME & FE & $\begin{array}{c}\text { Total } \\
\text { (ME + FE) }\end{array}$ \\
\hline Mean & & 37.8 & 63.06 \\
Standard Deviation & 25.3 & 10.2 & 2.9 \\
Kurtosis & 8.8 & -0.04 & -0.08 \\
Skewness & -0.54 & -0.15 & -0.19 \\
Minimum & 0.04 & 14 & 26 \\
Maximum & 8 & 60 & 99 \\
Sum & 43 & 1323 & 2207 \\
Possible Minimum & 864 & 0 & 0 \\
Possible Maximum & 0 & 60 & 108 \\
Possible Sum & 48 & 2100 & 3780 \\
\% achievements & 1680 & 63 & 58 \\
\hline
\end{tabular}

Table 4. Achievement of Mathematical Communication Skills for each Indicator

\begin{tabular}{|c|c|c|c|c|c|c|c|c|c|}
\hline \multirow{2}{*}{ Indicators } & \multicolumn{3}{|c|}{ ME } & \multicolumn{3}{|c|}{ FE } & \multicolumn{3}{|c|}{ Total } \\
\hline & Ach & $\%$ & Cat & Ach & $\%$ & Cat & Ach & $\%$ & Cat \\
\hline $\begin{array}{l}\text { Present the data or information in table or } \\
\text { diagram correctly }\end{array}$ & 143 & 51 & Medium & 278 & 66 & High & 421 & 60 & Medium \\
\hline $\begin{array}{l}\text { Use mathematical terms, symbols/notations, } \\
\text { charts, diagram, illustrations or formulas } \\
\text { correctly }\end{array}$ & 278 & 49 & Low & 431 & 62 & Medium & 709 & 56 & Medium \\
\hline Solve the problems correctly and systematically & 309 & 55 & Medium & 436 & 62 & Medium & 745 & 59 & Medium \\
\hline $\begin{array}{l}\text { Provide the correct reasons or explanations of } \\
\text { the solution they got }\end{array}$ & 154 & 55 & Medium & 178 & 64 & Medium & 332 & 59 & Medium \\
\hline Total & 884 & 52 & Medium & 1323 & 63 & Medium & 2207 & 58 & Medium \\
\hline
\end{tabular}

One of the problems used to measure the achievement of the second indicator is as follows: "Dari catatan tahuntahun sebelumnya diketahui bahwa hanya $30 \%$ dari peserta tes TOEFL yang dapat mencapai skor 500 pada tes yang dilakukannya pertama kali. Diketahui bahwa bulan depan ada ten mahasiswa yang akan mengikuti tes TOEFL untuk pertama kalinya. Jawablah pertanyaan berikut menggunakan notasi yang tepat. Berapa peluang bahwa: a) Sekurang-kurangnya ada 3 mahasiswa yang mencapai skor 500, dan b) Tidak ada mahasiswa yang mencapai skor 500." Translated in english as follows: "From the records of previous years, it is known that only $30 \%$ of TOEFL test participants can achieve a score of 500 on the first test. It is known that next month ten students will take the TOEFL test for the first time. Answer the following questions using proper notation. What is the probability that: (a) There are at least three students who achieve 500 scores, and (b) No student reaches a score of 500."

This question requires students to answer it using the right notation. However, most students do not use proper notation, including in writing what is known and what is asked. One example of student answers is seen in Fig. 1 as follows.

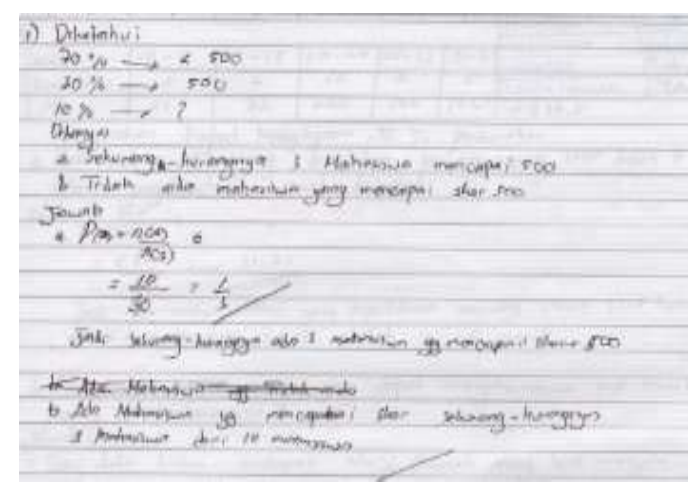

Fig. 1. Example of student answer

As shown in Fig. 1, it can be seen that the wrong answer from the student starts from the wrong writing. Suppose he wrote it as follows. $\mathrm{X}$ is the number of students who achieved a score of 500 on their first test. Then he writes what is required in the correct notation, namely: (a) $\mathrm{P}$ (X $\geq$ 3) and (b) $P(X=0)$, it is possible he can answer the problem correctly. Similarly, student answers are shown in Fig. 2 below. 


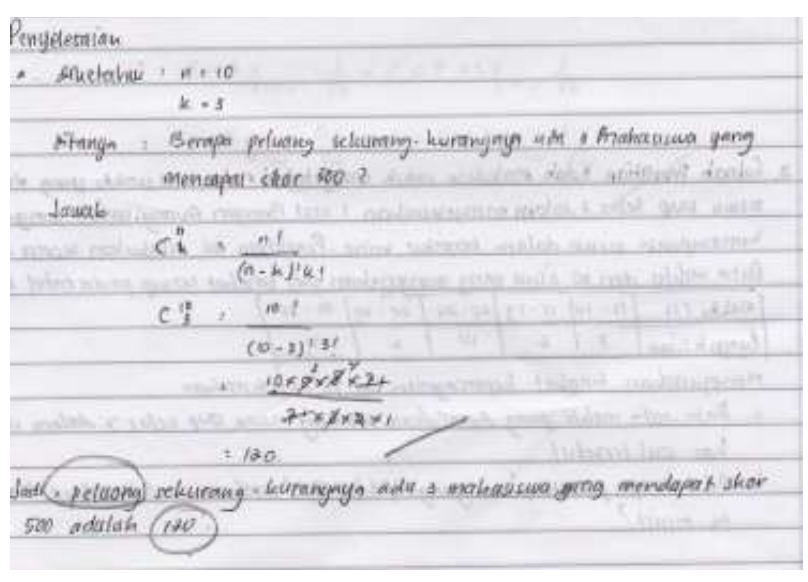

Fig. 2. Example of student answer

These two wrong answers from students, we can conclude that not only their mathematical communication skills that need to be improved but also their understanding of the concept, especially for the Probability material, related to the use of Permutation and Combination formulas. From the student exam results, both at $\mathrm{ME}$ and $\mathrm{FE}$, it is also known that the students' mastery of Probability material is relatively weak.

The topic about probability is difficult not only for the students but also for the teachers. For mathematics teachers, the topic of Probability also includes one of the most challenging topics to teach. According to Keeler and Steinhorst (2001), the probability unit in a first statistics course is challenging to teach because there is not much time, the concepts and mechanics are complicated, and the students do not see the relevance of their learning [12].

The results of this study reinforce the notion that probability problem-solving skills are closely related to students' ability in representation/communication [13]. It concludes that students who were able to use the coordinated approach by using multiple representations had better results in probability problem-solving.

The weakness of mathematical communication ability of this first-year student, besides influenced by concept understanding is also influenced by the habits of students at the previous school level. Many high school teachers do not familiarize students to write a complete answer. Besides, how teachers ask, or what words/phrases teachers use to ask, can also influence the development of students' mathematical communication skills.

Another cause is the habits of students practicing multiple choice questions. However, if the students work too often on multiple choice questions, then they will reduce their chances of answering the problem with the correct phrase and symbol. Although the national exam is in the form of multiple choice, a high school mathematics teacher should train his students to solve math problems completely, including using terms, symbols/notations, charts, diagram, illustrations or formulas correctly.

Many methods/strategies/approaches can be chosen by teachers/lecturers to improve students' mathematical communication skill. The results of Melianingsih and Sugiman show the effectiveness of the open-ended and problem-solving approach in improving mathematical communication skills of junior high school students [14]. Similarly, Hodiyanto's research results show the effect of the problem-solving approach in improving mathematical communication skills of junior high school students [15].

Not only are open-ended and problem-solving approaches can improve students' mathematical communication skills. The result of Hidayati's research also shows the effectiveness of Setting Think Pair Share in Discovery Learning Approach and Problem-Based Learning regarding students' mathematical communication skills [16]. In contrast, the results of Widjajanti's research show the influence of Problem-Based Collaborative Strategies in developing students' mathematical communication skills in a Discrete Mathematics course [11].

\section{CONCLUSION}

This research shows: 1) the students' mathematical communication skills in Statistics are at the medium level; 2) the ability to use correct mathematical terms, symbols/notations, charts, diagram, illustrations or formulas seems to be the lowest one among the four skills measured in this study; and 3) most students have difficulties in solving problems related to probability. The results indicate that the students' mathematical communication skills are serious issues that need to be addressed.

Based on the results of this study, it is suggested to mathematics teachers/lecturers to choose the right method/strategy/learning approach and to give many opportunities to the students to write a complete answer. The habit of writing down what is known, what is being asked, and explaining using terms, symbols/notations, charts, diagrams, illustrations or formulas correctly is essential to improve mathematical communication skills. A task such as "calculate" should start to be reduced by math teachers, since such questions are less likely to develop students' mathematical communication skills. Although in the end, the students have to do the calculation, the question can be replaced in such a way that besides the ability to perform counting operations, students also develop skills in mathematical communication. Teachers/lecturers are advised to use word/command like "why", "give reason", "what if ...", "simply", "draw", "explain", and so on.

\section{REFERENCES}

[1] B Trilling B and C Fadel, 21st Century Skills: Learning for Life in Our Times, John Wiley \& Sons, San Fransisco, 2009, pp. 45-84.

[2] K Amrai K, S E Motlagh, H A Zalani H A and H Parhon H, "The relationship between academic motivation and academic achievement students," Procedia Social and Behavioral Sciences vol. 15 pp. 399-402, 2011.

[3] T D A Sikhwari, "Study of the Relationship between Motivation, Self-concept and Academic Achievement of Students at a University in Limpopo Province, South Africa," Int J Edu Sci, vol. 6(1), pp. 19$25,2014$.

[4] G Berg and L R Coetzee L R, "Academic Self-concept and Motivation as Predictors of Academic Achievement," Int J Edu Sci, vol. 6(3), pp. 469-478, 2014.

[5] National Council of Teachers of Mathematics, Principles, and Standards for School Mathematics, NCTM, Reston, 2000.

[6] L Wichelt L, Communication: A Vital Skill of Mathematics, http://digitalcommons.unl.edu/, 2009. 
[7] GM Walk, Congress, and Bansho, Communication in the Mathematics Classroom, http://www.edu.gov.on.ca /eng/literacynumeracy/inspire/research/, 2010.

[8] J Hovermill, B Beaudrie, and B Boschmans B, "Statistical literacy requirements for teachers," International Conference on Teaching Statistics (ICOTS), 2014.

[9] A Ferligoj, "How to Improve Statistical Literacy?," Metodološki zvezki, vol. 12(1), pp. 1-10, 2015.

[10] D B Widjajanti, "The Communication Skills and Mathematical Connections of Prospective Mathematics Teacher: A Case Study on Mathematics Education Students, Yogyakarta State University, Indonesia," Jurnal Teknologi (Social Sciences), vol. 63(2), pp.39-43, 2013.

[11] National Council of Teachers of Mathematics, NCTM Program Standards, Programs for Initial Preparation of Mathematics Teachers, Standards for Secondary Mathematics Teachers. http://www.nctm.org/uploadedFiles/ Math_Standards/, 2003.

[12] C Keeler and K Steinhorst, "A New Approach to Learning Probability in the First Statistics Course," Journal of Statistics Education, vol. 9(3), 2001.
[13] S Anastasiadou, "Greek Students' Ability in Probability Problem Solving," Proceedings of CERME 6, pp. $404-412$, January 28thFebruary 1st 2009.

[14] Melianingsih and Sugiman, "Keefektifan pendekatan open-ended dan problem solving pada pembelajaran bangun ruang sisi datar di SMP,” Jurnal Riset Pendidikan Matematika, vol. 2(2), 2015.

[15] Hodiyanto, "Pengaruh model pembelajaran problem solving terhadap kemampuan komunikasi matematis ditinjau dari gender," Jurnal Riset Pendidikan Matematika, vol. 4(2), 2017.

[16] Hidayati, "Keefektifan setting TPS dalam pendekatan discovery learning dan problem-based learning pada pembelajaran materi lingkaran SMP," Jurnal Riset Pendidikan Matematika, vol. 4(1), 2017. 